\title{
Feeding Habits and Prey Consumption of Antarctic Minke Whale (Balaenoptera bonaerensis) in the Southern Ocean
}

\author{
Tsutomu Tamura and Kenji Konishi \\ The Institute of Cetacean Research, \\ 4-5 Toyomi-cho, Chuo-ku, Tokyo 104-0055, \\ Japan.E-mail: tamura@cetacean.jp
}

Tamura, T., and K. Konishi. 2009. Feeding habits and prey consumption of Antarctic minke whale (Balaenoptera bonaerensis) in the Southern Ocean. J. Northw. Atl. Fish Sci., 42: 13-25. doi:10.2960/J. v42.m652

\begin{abstract}
The Antarctic minke whale (Balaenoptera bonaerensis) is the most abundant baleen whale species in the Southern Ocean. Quantitative information on prey consumption of whales is useful to understand their feeding ecology and role in the ecosystem. The purposes of this study are 1) to investigate the feeding habit of Antarctic minke whales based on information on prey species, freshness and diurnal change in stomach contents, and 2) to estimate the amount of prey consumed by whales. Estimates are made for whales of different sexual maturity classes as it is expected that the energy requirements vary among them. The analysis is based on the data from whales taken by JARPA (Japanese Whale Research Program under Special Permit in the Antarctic) in a longitudinal sector between $35^{\circ} \mathrm{E}$ and $145^{\circ} \mathrm{W}$, and south of $60^{\circ} \mathrm{S}$. Sampling was conducted in the austral summer seasons from $1987 / 1988$ to $2004 / 2005$, mainly in the months from December to March. Daily prey consumption by the whales in each sexual maturity class was estimated using energy-requirement and energy deposition. The whales feed mainly before 05:00 h, which suggest that they cease to feed early in the day. Daily prey consumptions were estimated to be $83.7-325.5 \mathrm{~kg}$, equivalent to $2.7-4.0 \%$ of body weight. The mean prey consumptions per capita during feeding season were 7.5 and $16.4 \mathrm{t}$ for immature and mature male, 12.5 and $39.1 \mathrm{t}$ for immature and mature female, respectively. In Area IV $\left(70^{\circ}-130^{\circ} \mathrm{E}\right)$, total prey consumptions of krill by Antarctic minke whales in 1999/2000 and 2001/2002 seasons were estimated to be 0.9 and 1.1 million t, respectively. In Area V $\left(130^{\circ} \mathrm{E}-170^{\circ} \mathrm{W}\right.$ including the Ross Sea), these estimates in 2000/2001 and 2002/2003 seasons were 3.9 and 4.1 million t, respectively. The estimations of feeding impact on krill resources by Antarctic minke whales in Areas IV and V were from 2.7 to $3.2 \%$, and from 18.2 to $18.9 \%$ of krill biomasses, respectively. These results on prey consumption are important input data for the development of ecosystem modeling in the Southern Ocean.
\end{abstract}

Keywords: Antarctic minke whale, feeding habit, krill, prey consumption

\section{Introduction}

Determining the extent of the impact of predators on the ecosystem is an important factor to consider for the development of ecosystem models, which in turn could assist in the elaboration of multi-species management policies. The Southern Ocean has a simple food web with the Antarctic krill (Euphausia superba) as the key species. The consumption by some penguin and seal species on krill has been estimated (Doidge and Croxall, 1985; Boyd, 2002). For example, the prey consumption during austral summer of Antarctic fur seal (Arctocephalus gazella) around South Georgia was estimated to be 1.1 million $t$ (Doidge and Croxall, 1985). However quantitative information on consumption by baleen whales, the largest consumer group, is quite limited (Miller and Hampton, 1989).
The Antarctic minke whale (Balaenoptera bonaerensis) is the most abundant balaenopterid species in the Southern Ocean (IWC, 1991). Like other balaenopterid species (except the Bryde's whale B. edeni) the Antarctic minke whale spends its breeding season at lower latitude in austral winter and migrates to the Southern Ocean to feed in austral summer (Horwood, 1990; Kasamatsu et al., 1995). The Antarctic minke whale feeds mainly on Antarctic krill in offshore waters (Kawamura, 1980; Bushuev, 1986; Ichii and Kato, 1991), and on ice krill (E. crystallorophias) on the coastal shelf, such as Ross Sea and Prydz Bay (Bushuev, 1986; Tamura, MS 1998).

Previous studies estimated the daily prey consumption of the Antarctic minke whales in the Southern Ocean on the basis of energy-requirement calculations (Lockyer, 1981a; Armstrong and Siegfried, 1991; Reilly 
et al., 2004). None of these studies considered the fact that whales condition change with the progression of the feeding season. It is known that baleen whales store energy in their blubber and internal fat in the feeding season. Nordoy et al. (1995) estimated the food requirements of Northeast Atlantic minke whales based on energy stores. Therefore for the estimation of prey consumption it is important to assess the energy storage directly during feeding season of the minke whales.

In this study, the feeding habit and daily prey consumption of the Antarctic minke whales is examined based on a large data set obtained during the research surveys of the JARPA (Japanese Whale Research Program under Special Permit in the Antarctic) between the austral summer season $1987 / 1988$ and 2004/2005. The JARPA survey procedure was described by Nishiwaki et al. (MS 2006). It is expected that the output of this study will assist the understanding of the role of the Antarctic minke whale in the ecosystem and the development of ecosystem models for management purposes.

\section{Methods}

\section{Research area, period and number of samples}

Data used in the present study were collected during the surveys of the JARPA in the International Whaling Commission's (IWC) Antarctic management Areas IIIEast $\left(35^{\circ}-70^{\circ} \mathrm{E}\right), \mathrm{IV}\left(70^{\circ}-130^{\circ} \mathrm{E}\right), \mathrm{V}\left(130^{\circ} \mathrm{E}-170^{\circ} \mathrm{W}\right.$ including the Ross Sea) and VI-West $\left(170^{\circ}-145^{\circ} \mathrm{W}\right)$, and south of $60^{\circ} \mathrm{S}$ (Fig. 1). The surveys were conducted in the austral summer seasons (December-March) from $1987 / 1988$ to $2004 / 2005$ seasons. During the surveys

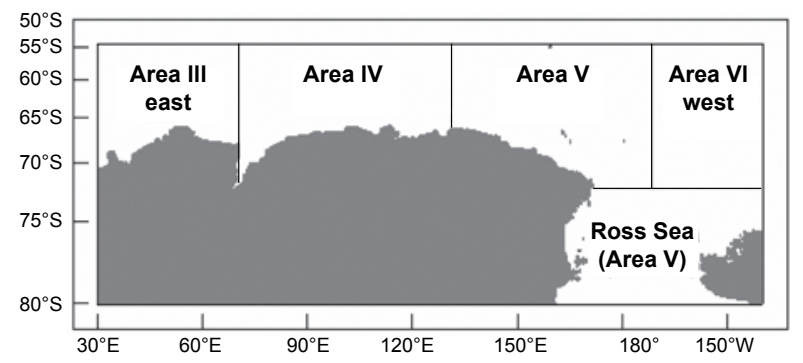

Fig. 1. Research area in the Antarctic. a total of 6777 Antarctic minke whales were sampled. Table 1 shows the number of samples by area and sex. After sampling whales were brought to the research base vessel where animals were examined by biologists onboard. All whales were sampled during daylight hours, between 03:00 and 21:00 h.

\section{Treatments of stomach contents}

All balaenopterid species have four chambered stomach compartments (Hosokawa and Kamiya, 1971; Olsen et al., 1994). Stomach contents were removed from each compartments and weighed to the nearest $0.1 \mathrm{~kg}$. The analysis of prey consumption in this study was based on data collected from the first compartment (forestomach) and second compartment (fundus). To examine the daily feeding rhythms of the minke whale the freshness of preys in the forestomach were categorized into four digestion levels

$$
\begin{aligned}
\mathrm{F}= & \text { fresh (prey not affected by digestion, } \\
\mathrm{fff}= & \text { lightly digested (prey slightly affected by } \\
& \text { digestion), } \\
\mathrm{ff}= & \text { moderately digested (prey moderately to } \\
& \text { highly fragmented), and } \\
\mathrm{f}= & \text { heavily digested (unidentifiable remains } \\
& \text { or indigestible parts only). }
\end{aligned}
$$

Because of uniformity of prey within the stomachs of almost all whales, after checking the stomach contents, some fresh prey $(200 \mathrm{~g})$ in the forestomach or fundus were collected and stored in $10 \%$ formalin for species identification at the laboratory. Prey species were identified to the lowest taxonomic level as possible using external morphology (Barnard, 1932; Fischer and Hureau, 1985a, b; Baker et al., 1990).

\section{Biological data}

An estimate of the daily prey consumption requires the use of some additional biological and morphometric data. Body length of the whales was measured to the

\begin{tabular}{|c|c|c|c|c|c|c|c|c|c|c|}
\hline \multirow{2}{*}{$\begin{array}{l}\text { Area } \\
\text { Sex }\end{array}$} & \multicolumn{2}{|c|}{ Area III-East } & \multicolumn{2}{|c|}{ Area IV } & \multicolumn{2}{|c|}{ Area V } & \multicolumn{2}{|c|}{ Area VI-West } & \multicolumn{2}{|c|}{ Total } \\
\hline & Male & $\overline{\text { Female }}$ & Male & $\overline{\text { Female }}$ & Male & $\overline{\text { Female }}$ & Male & $\overline{\text { Female }}$ & Male & $\overline{\text { Female }}$ \\
\hline Number & 322 & 227 & 1565 & 1298 & 1419 & 1446 & 320 & 180 & 3626 & 3151 \\
\hline
\end{tabular}
nearest $10 \mathrm{~cm}$ from the tip of the upper jaw to the deepest part of the fluke notch in a straight line. The whole body of whales was weighed using a large scale installed on the flensing deck. For some individuals muscle, blubber and internal organs were weighted for calculating the

TABLE 1. Sample size used in this study. 
energy deposited during the feeding season. A correction factor for blood loss was not calculated in this study.

Energy requirements are different for different sexual maturity classes, therefore estimations of the daily prey consumption in this study took into consideration information on sexual maturity. Sexual maturity of Antarctic minke whales was defined in accordance with Kato et al. (1990). Males with a single testis weight of $400 \mathrm{~g}$ or more was defined as sexually mature. Females with at least one corpus luteum or albicans in their ovaries were defined sexually mature.

\section{Analytical procedure for the daily prey consumption}

The daily prey consumption in each sexual maturity class was estimated from the standard metabolic rate and energy deposit according to the following equations:

$$
\begin{aligned}
& \text { Male or Immature female: } \\
& \qquad D_{k g}=\left(S M R_{k J}+E D_{k J}\right) / E_{K J} \\
& \text { Mature female: } \\
& \qquad D_{k g}=\left(S M R_{k J}+E D_{k J}+R_{k J}\right) / E_{K J}
\end{aligned}
$$

Where $D_{k g}$ is daily prey consumption $\left(\mathrm{kg} \mathrm{d}^{-1}\right), S M R_{k J}$ is standard metabolic rate $\left(\mathrm{kJ} \mathrm{d}^{-1}\right), E D_{K J}$ is Energy deposition $\left(\mathrm{kJ} \mathrm{d}^{-1}\right), R$ is Reproduction cost $\left(\mathrm{kJ} \mathrm{kg}^{-1}\right)$ and $E_{k J}$ is caloric value of prey species $\left(\mathrm{kJ} \mathrm{kg}^{-1}\right)$. The details of these items are described as follow:

Standard metabolic rate $\left(S M R_{k J}\right)$. To account for energy spent on activities such as foraging, moving between food patches and migration the standard metabolic rate $\left(S M R_{k,}, \mathrm{~kJ} \mathrm{~d}^{-1}\right)$ was calculated using the following equation (Markussen et al., 1992):

$$
S M R_{k J}=1.45 \times B M R \times 4.184
$$

The basal metabolic rate $\left(B M R, \mathrm{kcal} \mathrm{d}^{-1}\right)$ was calculated following Kleiber's equation (Kleiber, 1961):

$$
B M R=70 M^{0.75}
$$

where $M$ is the Antarctic minke whale body weight $(\mathrm{kg})$. The value of 1.45 is the coefficient for energy spent on activities such as foraging, moving between food patches and migration. The value of 4.184 is the conversion factor from Kcal to KJ.

Energy deposited during feeding season in Antarctic $\left(\boldsymbol{E} \boldsymbol{D}_{k J}\right)$. The total muscle, blubber and internal organs weight of some Antarctic minke whales were weighed to calculate seasonal growth and fat deposition. In this study the deposition were converted to energy deposition by measuring the energy density of muscle and blubber of some whales sampled in the early and late seasons during austral summer by bomb calorimeter ( $n=1$ in each sexual category).
The weight of others fat deposition (e.g. internal organs) was estimated to deduct the weight of blubber deposition and the weight of muscle deposition from total body weight.

Reproduction cost $\left(\boldsymbol{R}_{K J}\right)$. The $R_{K J}$ for a female Antarctic minke whale was calculated by Lockyer (1981a) to be $1.89 \times 10^{6} \mathrm{~kJ}$, assuming that the length at birth is $273 \mathrm{~cm}$ (Best, 1982). We assumed that almost all mature female were pregnant, and that all reproduction cost took during feeding season (120 days). The $R_{K J}$ for a female Antarctic minke whale was calculated to be $158 \times 10^{3} \mathrm{~kJ} \mathrm{~d}^{-1}$.

Energy value of Euphausia superba $\left(E_{K J}\right)$. Antarctic minke whales feed mainly on E. superba. The energy value is $4473 \mathrm{~kJ} \mathrm{~kg}^{-1}$. In this study this value was measured by bomb calorimeter $(n=1)$. We assumed the same value for other prey items such as E. crystallorophias. Lockyer (1981a) estimated that Antarctic minke whales had an assimilation efficiency of $84 \%$. We used same value as assimilation efficiency for calculating of daily prey consumption. Therefore energy value of prey items of whales was estimated to be $3757 \mathrm{~kJ} \mathrm{~kg}^{-1}$.

Feeding period. The encounter rate (as a simple index of distribution density) of Antarctic minke whales in the Antarctic increased from early November to late December and peak in January, followed by a steady decrease through February (Kasamatsu et al., 1996). Immature animals and mature males spend 90 days in the feeding grounds, mature females spend 120 days (Lockyer, 1981a, b). We also assumed that immature animals and mature male spend 90 days, mature female spend 120 days, respectively. The total prey consumption during feeding season $\left(S D_{k g}\right)$ was applied as following:

Immature animals and mature male:

$$
\begin{aligned}
& S D_{k g}=90 D_{k g} \\
& \text { Mature female: } \\
& S D_{k g}=120 D_{k g}
\end{aligned}
$$

\section{Estimation of total prey consumption in Areas IV and $V$}

The total prey consumption by Antarctic minke whales in Areas IV and V from 1999/2000 to 2002/2003 seasons was estimated using information on abundance in these Areas (Hakamada et al., MS 2006) and the composition of the Antarctic minke whales by sex and sexual maturity status based on JARPA data.

Furthermore, we also estimated the feeding impact on krill resources by the minke whales in Area IV and V of the Antarctic from 1999/2000 to 2002/2003 seasons. 
The biomass of krill resources were estimated by acoustic survey as described in Murase et al. (MS 2006).

\section{Results}

\section{Prey species composition}

A total of ten prey species, one amphipod (Parathemisto gaudichaudi), four euphausiids (Euphausia superba, E. crystallorophias, E. frigida, Thysanoessa macrura) and five fishes (Pleragramma antarcticum, Notolepis coatsi, Electona antarctica, Chinodraco sp. and Notothenis sp.), were identified from the stom- achs of the Antarctic minke whales. The Antarctic krill was dominant prey species, occurring in $85-100 \%$ by weight composition of the whales examined in each area (Table 2, Figs. 2a, b), followed by ice krill, two euphausiids (E. frigida, T. macrura), one amphipod (P. gaudichaudi) and one fish species (P. antarcticum).

\section{Diurnal changes in feeding activity}

The composition of freshness categories and the diurnal change in the mean of the ratio of stomach contents weight to body weight, expressed as a percentage (RSC), is shown in Figs. 3 and 4. These figures show that the



Fig. 2. (A) Sampling position of Antarctic minke whales and their dominant prey species in Areas III-East and IV. Line shows water depth contour of $1000 \mathrm{~m}$. 


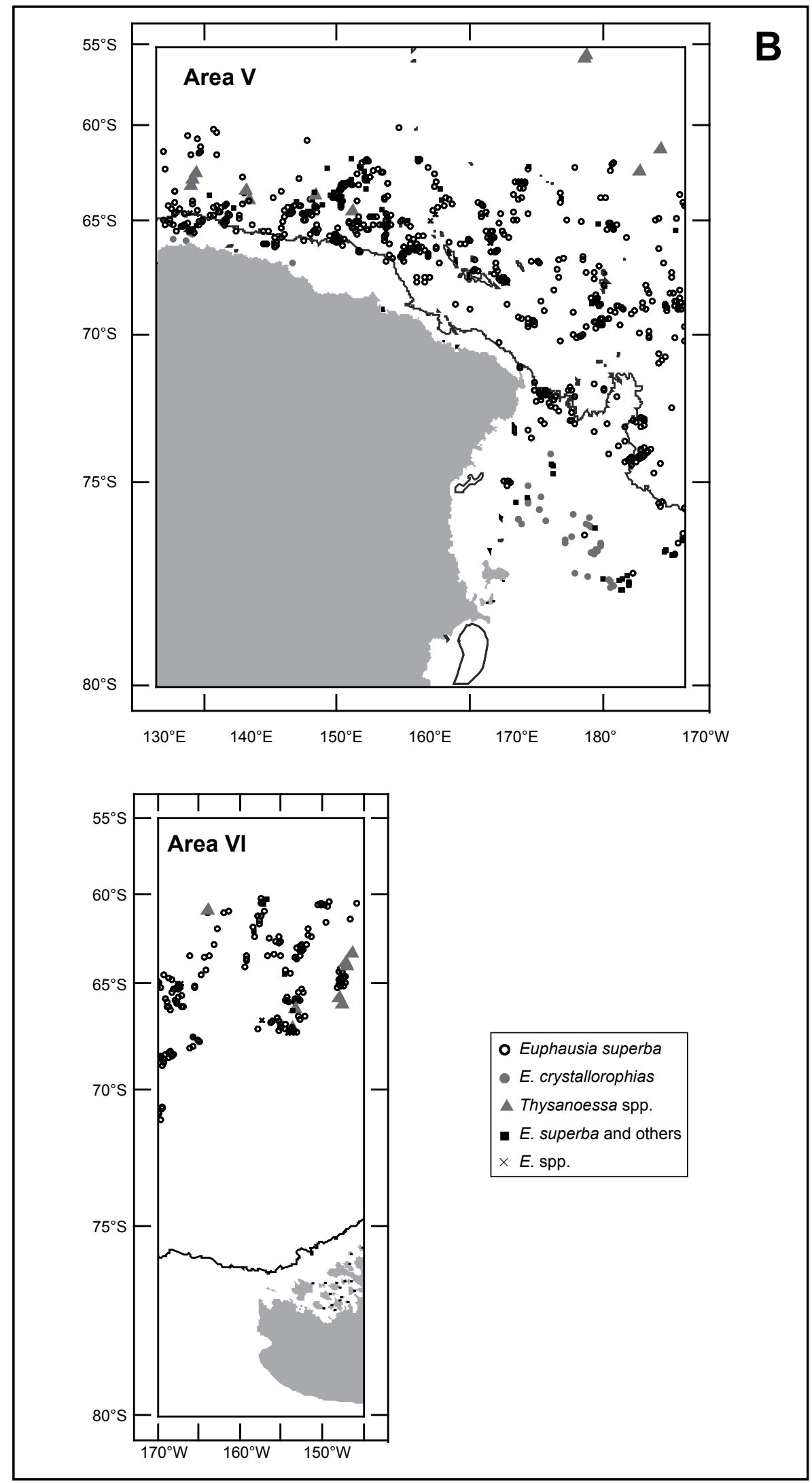

Fig. 2. (B) Sampling position of Antarctic minke whales and their dominant prey species in Areas V and VI-West. Line shows water depth contour of $1000 \mathrm{~m}$. 
TABLE 2. Occurrence ( $\%$ by weight composition) of main prey species found in the stomachs of Antarctic minke whales sampled by JARPA surveys.

\begin{tabular}{llcrrc}
\hline \hline Species & & Area III-E & Area IV & Area V & Area VI-W \\
\hline Krill & Euphausia superba & 99.5 & 95.2 & 85.4 & 93.0 \\
& E. crystallorophias & 0.1 & 2.7 & 11.5 & 0.0 \\
& E. frigida & 0.4 & 0.0 & 0.2 & 0.0 \\
& Thysanoessa macrura & 0.0 & 2.1 & 2.9 & 6.8 \\
Ampipods & Parathemisto gaudichaudi & 0.0 & 0.1 & 0.1 & 0.0 \\
Fish & Pleuragramma antarcticum & 0.0 & 0.0 & 0.2 & 0.0 \\
\hline
\end{tabular}

proportion of fresh and lightly digested categories and the rate of the mean stomach content weight had gradually decreased from early morning to afternoon. After 19:00 $\mathrm{h}$, the fresh categories and the weight of the mean stomach content weight showed a slight increase.

\section{Stomach contents weight}

The mean and maximum weight of stomach contents of different reproductive classes are shown in Table 3. The mean weight of fresh or lightly digested stomach contents (freshness category $\mathrm{F}$ and $\mathrm{fff}$ ) were $30.9 \pm 23.5 \mathrm{~kg}$ (RSC: $1.0 \%$ ) and $43.0 \pm 31.5 \mathrm{~kg}$ (RSC: $1.0 \%$ ) for immature males and females, respectively and $74.2 \pm 50.1 \mathrm{~kg}$ (RSC: $1.1 \%$ ) and $76.3 \pm 54.6 \mathrm{~kg}$ (RSC: $1.0 \%$ ) for mature males and females, respectively.

The maximum weight of stomach contents (category $\mathrm{F}$ and fff) were $125.7 \mathrm{~kg}$ (RSC: $3.1 \%$ ) and $156.0 \mathrm{~kg}$ (RSC: $3.4 \%$ ) for immature males and females, respectively and $343.8 \mathrm{~kg}$ (RSC: $4.2 \%$ ) and $321.2 \mathrm{~kg}$ (RSC: $3.6 \%$ ) for mature males and females, respectively.

\section{Daily prey consumption}

Body weight of whales. The average body lengths were $6.1 \pm 0.7$ (Average \pm S.D) and $8.4 \pm 0.4 \mathrm{~m}$ for immature and mature males, and $6.7 \pm 1.0$ and $8.9 \pm 0.4 \mathrm{~m}$ for immature and mature females, respectively. The mean body weight was $2900 \pm 1000$ and $6800 \pm 1100 \mathrm{~kg}$ for immature and mature males, and $3800 \pm 1600$ and $8100 \pm 1200 \mathrm{~kg}$ for immature and mature females, respectively. $S M R_{k J}$ of immature and mature males were $168 \times 10^{3}$ and $318 \times 10^{3} \mathrm{~kJ}$, respectively. $S M R_{k J}$ of immature and mature females were $206 \times 10^{3}$ and $363 \times 10^{3} \mathrm{~kJ}$, respectively (Table 4).

Energy deposited during feeding season. There was an increase in the energy density of blubber of males from 14435 to $20711 \mathrm{~kJ} \mathrm{~kg}^{-1}$ (wet weight) and of females from 16443 to $28075 \mathrm{~kJ} \mathrm{~kg}^{-1}$ (wet weight) between December and March. There was also an increase

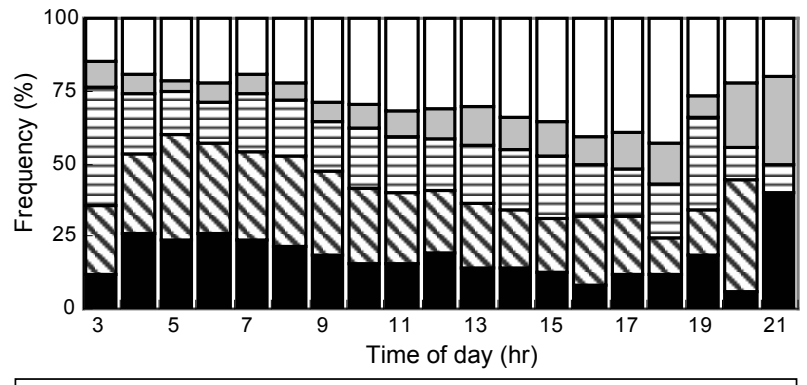

fresh (F) $\mathbf{\nabla}$ lightly digested (fff) $⿴$ 目 moderately digested (ff) $\square$ heavily digested (f) $\square$ empty (0)

Fig. 3. Composition of prey freshness categories throughout the day in the Antarctic minke whale.

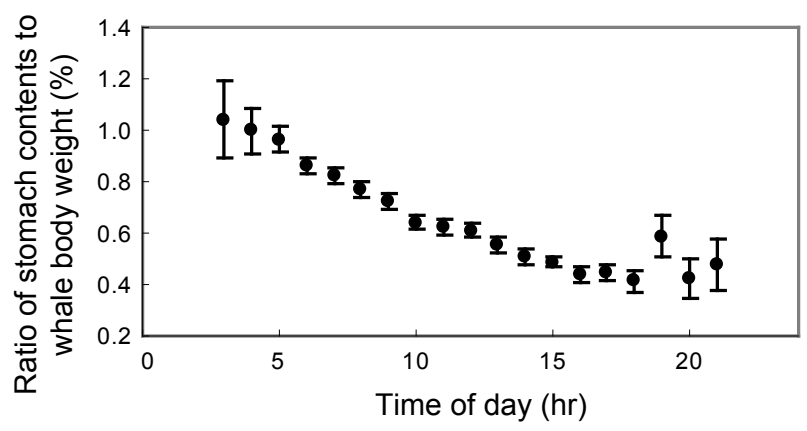

Fig. 4. Change in the ratio of stomach contents to whale body weight (RSC) throughout the day. Error bars are \pm 1 S.E.

in the energy density of muscle of males from 5858 to $6234 \mathrm{~kJ} \mathrm{~kg}^{-1}$ (wet weight) and of females from 5941 to $6192 \mathrm{~kJ} \mathrm{~kg}^{-1}$ (wet weight) between December and March (Table 5).

Fig. 5 shows the relationship between blubber weight ( $\mathrm{t}$ ) and body length ( $\mathrm{m})$, by sex and maturity class. Immature and mature males had an increase in blubber energy contents per day of $69610 \mathrm{~kJ}$ and $162664 \mathrm{~kJ}$, respectively. Immature and mature females had an increase in blubber energy contents per day of $144620 \mathrm{~kJ}$ and $303619 \mathrm{~kJ}$, respectively (Table 4). 
TABLE 3. Stomach contents weight ( $\mathrm{kg})$ of Antarctic minke whales. RSC is ratio of stomach contents weight to body weight expressed as a percentage.

\begin{tabular}{|c|c|c|c|c|c|}
\hline \multirow[b]{2}{*}{ Sex } & \multirow[b]{2}{*}{ Maturity } & \multirow[b]{2}{*}{ Number } & \multicolumn{3}{|c|}{ Contents weight $(\mathrm{F}+\mathrm{fff})$} \\
\hline & & & Average & S.D. & Maximum \\
\hline \multirow[t]{4}{*}{ Male } & Immature & 182 & 30.9 & 23.5 & 125.7 \\
\hline & & & (RSC: $1.0 \%)$ & & (RSC: $3.1 \%$ ) \\
\hline & Mature & 1180 & 74.2 & 50.1 & 343.8 \\
\hline & & & (RSC: $1.1 \%$ ) & & (RSC: $4.2 \%$ ) \\
\hline \multirow[t]{4}{*}{ Female } & Immature & 321 & 43.0 & 31.5 & 156.0 \\
\hline & & & (RSC: $1.0 \%$ ) & & (RSC: $3.4 \%$ ) \\
\hline & Mature & 756 & 76.3 & 54.6 & 321.2 \\
\hline & & & (RSC: $1.0 \%)$ & & (RSC: $3.6 \%$ ) \\
\hline
\end{tabular}

TABLE 4. Required energy contents $\left(\mathrm{KJ} \mathrm{d}^{-1}\right)$ of Antarctic minke whales.

\begin{tabular}{llccccccc}
\hline \hline Sex & Maturity & $\begin{array}{c}\text { Body } \\
\text { length } \\
(\mathrm{m})\end{array}$ & $\begin{array}{c}\text { Mean body } \\
\text { weight } \\
(\mathrm{kg})\end{array}$ & $\begin{array}{c}\mathrm{SMR} \\
\left(\mathrm{KJ} \mathrm{d}^{-1}\right)\end{array}$ & $\begin{array}{c}\text { Blubber } \\
\text { deposition } \\
\left(\mathrm{KJ} \mathrm{d}^{-1}\right)\end{array}$ & $\begin{array}{c}\text { Muscle } \\
\text { deposition } \\
\left(\mathrm{KJ} \mathrm{d}^{-1}\right)\end{array}$ & $\begin{array}{c}\text { Others fat } \\
\text { deposition } \\
\left(\mathrm{KJ} \mathrm{d}^{-1}\right)\end{array}$ & $\begin{array}{c}\text { Reproduc- } \\
\text { tion cost } \\
\left(\mathrm{KJ} \mathrm{d}^{-1}\right)\end{array}$ \\
\hline Male & Immature & 6.1 & 2900 & 167825 & 69610 & 24698 & 52535 & \\
& Mature & 8.4 & 6800 & 318009 & 162664 & 50245 & 151704 \\
Female & Immature & 6.7 & 3800 & 205540 & 144620 & 20088 & 150950 & \\
& Pregnant & 8.9 & 8100 & 362595 & 303619 & 31175 & 368105 & 157500 \\
\hline
\end{tabular}

Fig. 6 shows the relationship between muscle weight (t) and body length (m), by sex and maturity class. Immature and mature males had an increase in muscle energy contents per day of $24698 \mathrm{~kJ}$ and $50245 \mathrm{~kJ}$, respectively. Immature and mature female had an increase in muscle energy contents per day of $20088 \mathrm{~kJ}$ and $31175 \mathrm{~kJ}$, respectively (Table 4).

The weight of others fat deposition (e.g. internal organs) was estimated to deduct the weight of blubber deposition and the weight of muscle deposition from total body weight (Figs. 5, 6 and 7). Immature and mature male had an increase in others fat energy contents per day of $52535 \mathrm{~kJ}$ and $151704 \mathrm{~kJ}$, respectively. Immature and mature female had an increase in muscle energy contents per day of $150950 \mathrm{~kJ}$ and $368105 \mathrm{~kJ}$, respectively (Table 4).

Daily and seasonal prey consumption. The calculated daily energy requirements during feeding season were $315 \times 10^{3}$ and $683 \times 10^{3} \mathrm{~kJ}$ for immature and mature male, and $521 \times 10^{3}$ and $1223 \times 10^{3} \mathrm{~kJ}$ for immature and mature female, respectively (Table 6).
TABLE 5. Energy value of blubber and muscle $\left(\mathrm{KJ} \mathrm{kg}^{-1}\right)$ of Antarctic minke whales.

\begin{tabular}{lcclcc}
\hline & \multicolumn{2}{c}{ Blubber $\left(\mathrm{KJ} \mathrm{kg}^{-1}\right)$} & & \multicolumn{2}{c}{ Muscle $\left(\mathrm{KJ} \mathrm{kg}^{-1}\right)$} \\
\cline { 2 - 3 } \cline { 5 - 6 } Sex & December & March & & December & March \\
\hline Male & 14435 & 20711 & & 5858 & 6234 \\
Female & 16443 & 28075 & & 5941 & 6192 \\
\hline
\end{tabular}

When the mean energy value of prey of $4473 \mathrm{~kJ} \mathrm{~kg}^{-1}$ and the assimilation efficiency of $84 \%$ were assumed, the daily prey consumptions during feeding season were 83.7 and $181.7 \mathrm{~kg}$ for immature and mature male, and 138.7 and $325.5 \mathrm{~kg}$ for immature and mature female, respectively. These values were equivalent to 2.9 and $2.7 \%$ of mean body weight for immature and mature male, and 3.7 and $4.0 \%$ of mean body weight for immature and mature female, respectively (Table 6).

The seasonal prey consumptions per capita during feeding season were 7.5 and $16.4 \mathrm{t}$ for immature and mature male, and 12.5 and $39.1 \mathrm{t}$ for immature and mature female, respectively (Table 6). 

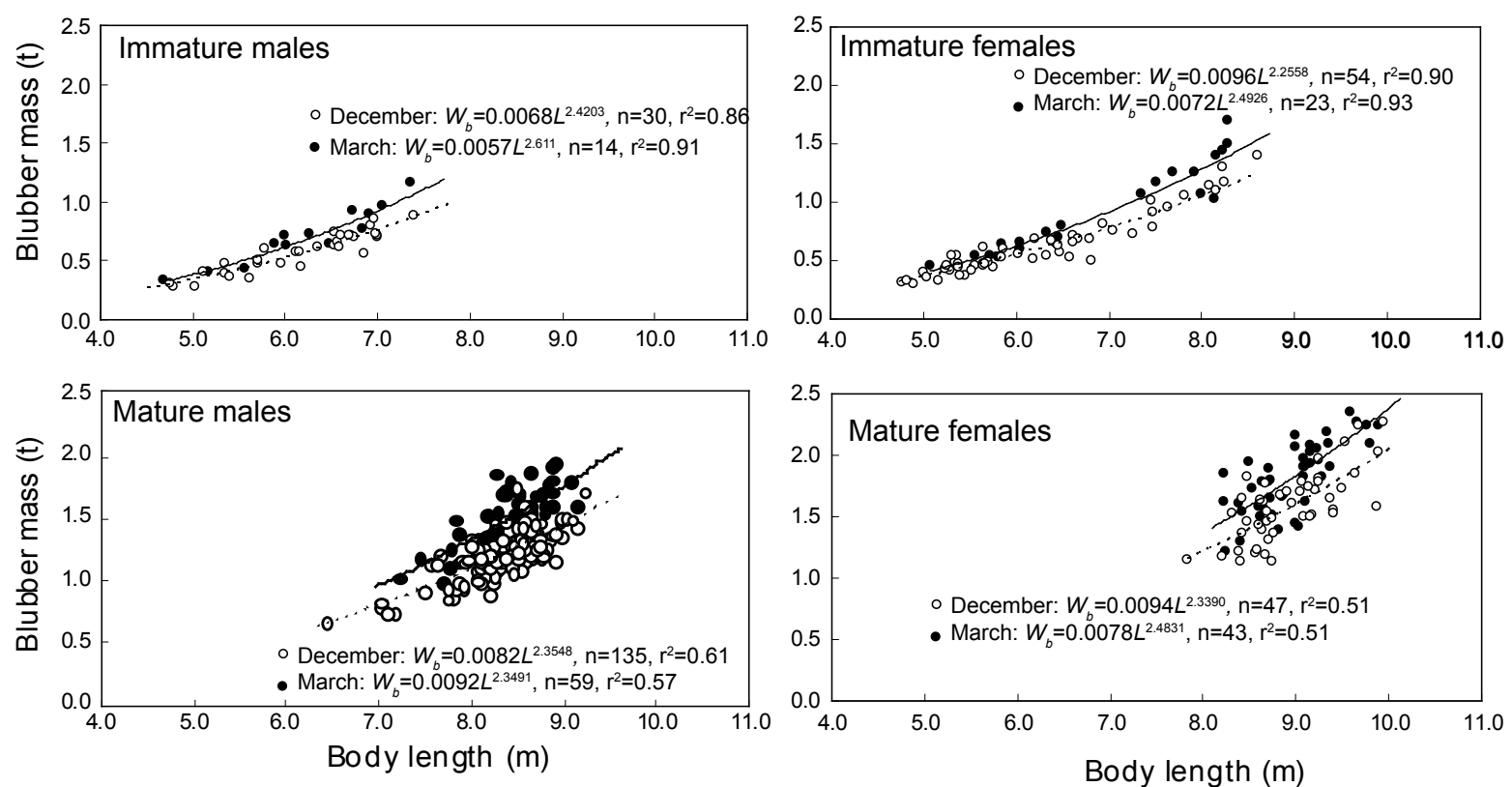

Fig. 5. The blubber weight $\left(W_{b}, \mathrm{t}\right)$ as a function of body length $(L, \mathrm{~m})$ for Antarctic minke whale sampled in December and March.
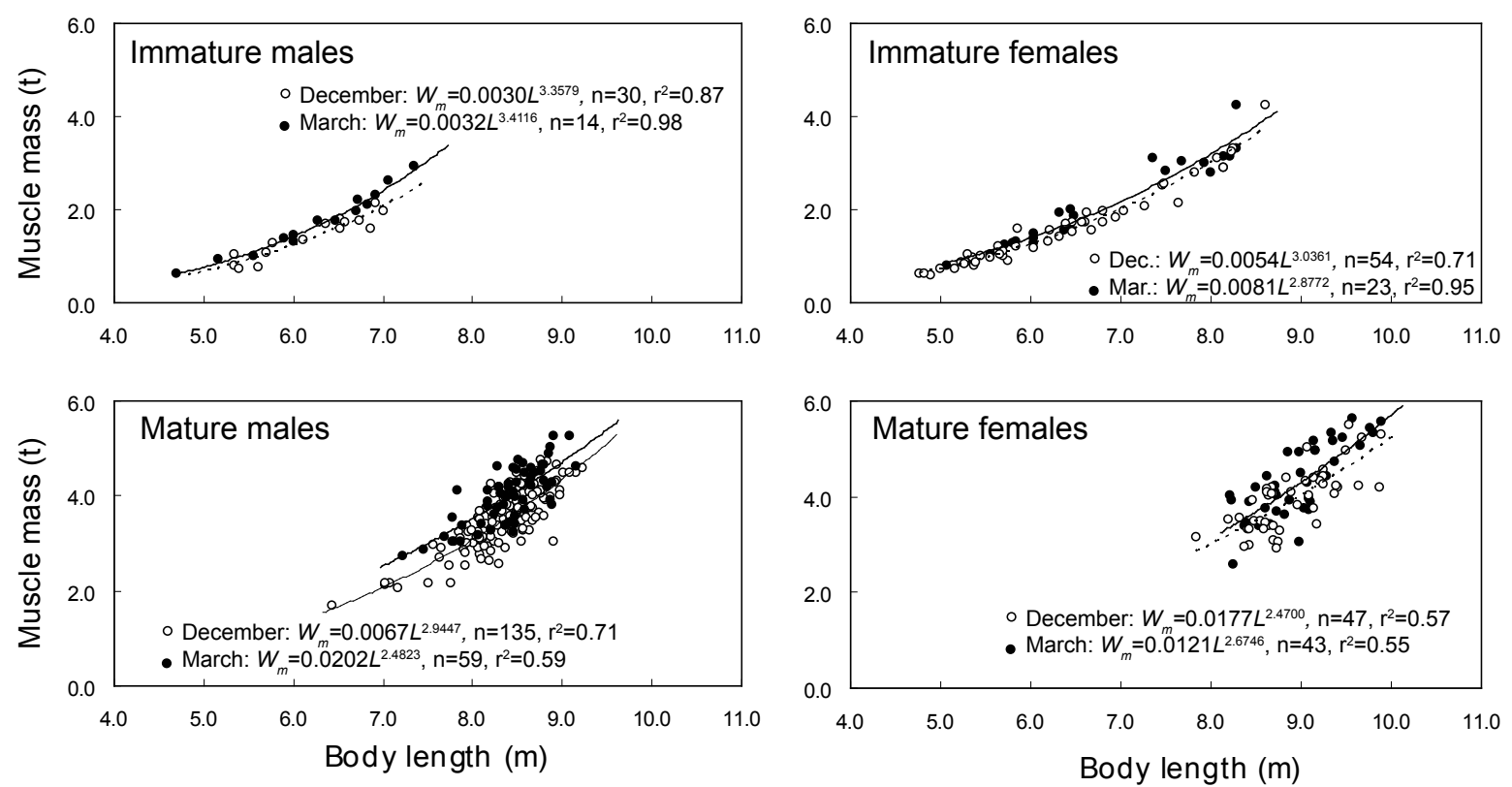

Fig. 6. The muscle weight $\left(W_{m}, \mathrm{t}\right)$ as a function of body length $(L, \mathrm{~m})$ for Antarctic minke whales sampled in December and March.

Feeding impact on krill resources by Antarctic minke whales in Areas IV and V in the Antarctic

Abundance of Antarctic minke whales in Areas $\boldsymbol{I V}$ and $\boldsymbol{V}$. The abundance of Antarctic minke whales in Areas IV and V was estimated based on sighting data collected during the JARPA as described in Hakamada et al. (MS 2006). In Area IV in 1999/2000 and 2001/2002 seasons, the abundance was estimated to be 44931 and 48 280, respectively. In Area $\mathrm{V}$ in 2000/2001 and $2002 / 2003$ seasons, the abundance was estimated to be 160997 and 175 985, respectively (Table 7).

Biomass of Antarctic krill in Areas IV and $V$. The krill biomass was estimated by acoustic survey conducted under the JARPA as described in Murase et al. (MS 
TAMURA and KONISHI: Feeding Habit and Prey Consumption of Antarctic Minke Whale
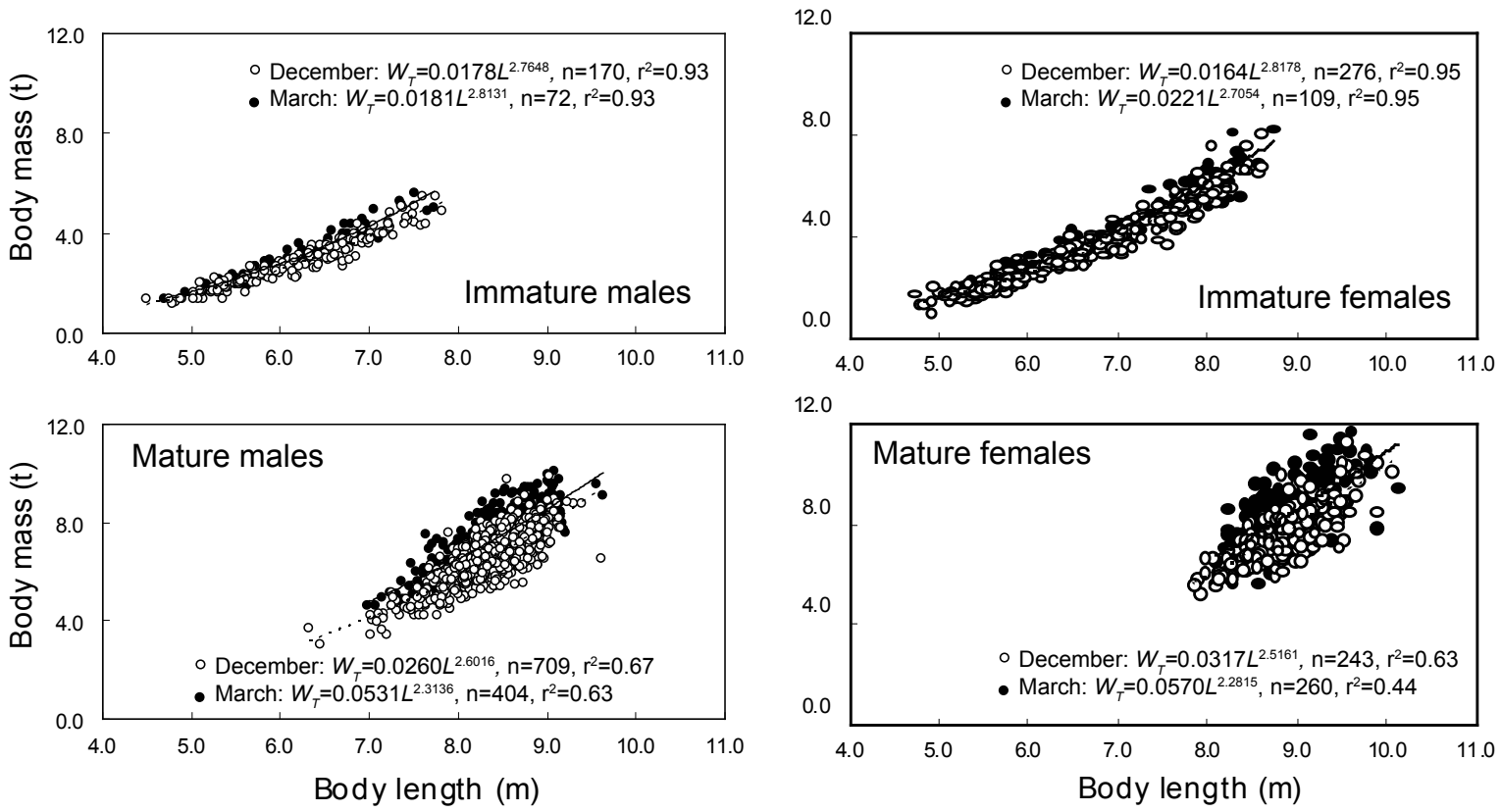

Fig. 7. Total body weight $\left(W_{T}, \mathrm{t}\right)$ as a function of body length $(L, \mathrm{~m})$ for Antarctic minke whales sampled in December and March.

TABLE 6. The daily and seasonal prey consumption of Antarctic minke whales.

\begin{tabular}{|c|c|c|c|c|c|c|c|}
\hline \multirow[b]{2}{*}{ Sex } & \multirow[b]{2}{*}{ Maturity } & \multirow{2}{*}{$\begin{array}{l}\text { Body } \\
\text { length } \\
(\mathrm{m})\end{array}$} & \multirow{2}{*}{$\begin{array}{c}\text { Mean body } \\
\text { weight } \\
\text { (B.W., kg) }\end{array}$} & \multicolumn{3}{|c|}{$\begin{array}{l}\text { Daily prey consumption during } \\
\text { feeding season }\end{array}$} & \multirow{2}{*}{$\begin{array}{c}\text { Seasonal } \\
\text { consumption } \\
\text { (t) }\end{array}$} \\
\hline & & & & $\left(\mathrm{KJ} \mathrm{d}^{-1}\right)$ & $\left(\mathrm{kg} \mathrm{d}^{-1}\right)$ & (\% of B.W.) & \\
\hline \multirow[t]{2}{*}{ Male } & Immature & 6.1 & 2900 & 314668 & 83.7 & 2.9 & 7.5 \\
\hline & Mature & 8.4 & 6800 & 682622 & 181.7 & 2.7 & 16.4 \\
\hline \multirow[t]{2}{*}{ Female } & Immature & 6.7 & 3800 & 521198 & 138.7 & 3.7 & 12.5 \\
\hline & Pregnant & 8.9 & 8100 & 1222994 & 325.5 & 4.0 & 39.1 \\
\hline
\end{tabular}

2006). In Area IV in 1999/2000 and 2001/2002 seasons, the biomass was estimated to be 34.2 and 34.1 million t, respectively. In Area V in 2000/2001 and 2002/2003 seasons, the biomass was estimated to be 20.7 and 22.6 million $\mathrm{t}$, respectively (Table 8 ).

Total prey consumption and feeding impact. In Area IV, total prey consumptions of krill by Antarctic minke whales of 1999/2000 and 2001/2002 season were estimated to be 0.9 and 1.1 million $t$, respectively. On the other hand, in Area V, total prey consumptions of krill by Antarctic minke whales of 2000/2001 and 2002/2003 season were estimated to be between 3.9 and 4.1 million $\mathrm{t}$, respectively (Table 7).

The estimations of feeding impact on krill resources by Antarctic minke whales in Areas IV and V were from
2.7 to $3.2 \%$, and from 18.2 to $18.9 \%$ of krill biomass, respectively (Table 8 ).

\section{Discussion}

\section{Diversity of prey species}

The main prey species of Antarctic minke whales during austral summer were two krill species. Consumption of these species depended on the distributional difference of the krill species. The Antarctic minke whales fed mostly on Antarctic krill in offshore area, and ice krill in coastal (shallow) area on continental shelf such as Ross Sea and Prydz Bay. It is strongly suggested that Antarctic minke whale feed on local predominant prey species. Ice krill is a dominant euphausiid on the continental shelf (Water depth $<1000 \mathrm{~m}$ ), the occurrence of Antarctic krill 
TABLE 7. The seasonal prey consumption of Antarctic minke whales in Areas IV and V. The abundance of whales was estimated by Hakamada et al. (MS 2006).

\begin{tabular}{|c|c|c|c|c|c|c|c|c|c|c|c|c|c|c|c|}
\hline \multicolumn{16}{|c|}{ Area lV } \\
\hline \multirow[b]{2}{*}{ Stratum } & \multirow[b]{2}{*}{ Year } & \multirow{2}{*}{$\begin{array}{l}\text { Abundance } \\
\text { (inds.) }\end{array}$} & \multicolumn{4}{|c|}{ Composition (\%) } & \multicolumn{4}{|c|}{ Abundance (inds.) } & \multicolumn{5}{|c|}{$\begin{array}{l}\text { Seasonal consumption in Antarctic } \\
\text { (million } \mathrm{t})\end{array}$} \\
\hline & & & $\mathrm{IM}$ & MM & IF & MF & $\mathrm{IM}$ & MM & IF & MF & $\mathrm{IM}$ & MM & IF & MF & Total \\
\hline \multirow[t]{2}{*}{ Total } & $1999 / 00$ & 44931 & 11.9 & 41.2 & 21.4 & 25.5 & 5347 & 18512 & 9615 & 11457 & 0.04 & 0.30 & 0.12 & 0.45 & 0.91 \\
\hline & $2001 / 02$ & 48280 & 9.6 & 36.1 & 20.2 & 34.1 & 4635 & 17429 & 9753 & 16463 & 0.03 & 0.29 & 0.12 & 0.64 & 1.08 \\
\hline \multicolumn{16}{|c|}{ Area V } \\
\hline \multirow[t]{2}{*}{ West } & $2000 / 01$ & 19608 & 17.1 & 50.7 & 13.6 & 18.6 & 3361 & 9944 & 2661 & 3641 & 0.03 & 0.16 & 0.03 & 0.14 & 0.36 \\
\hline & $2002 / 03$ & 100775 & 6.0 & 48.0 & 10.0 & 36.0 & 6047 & 48372 & 10078 & 36279 & 0.05 & 0.79 & 0.13 & 1.42 & 2.38 \\
\hline \multirow[t]{2}{*}{ East } & $2000 / 01$ & 141389 & 10.5 & 37.4 & 7.9 & 44.2 & 14883 & 52835 & 11163 & 62509 & 0.11 & 0.86 & 0.14 & 2.44 & 3.56 \\
\hline & $2002 / 03$ & 75210 & 13.5 & 36.1 & 13.9 & 36.5 & 10137 & 27141 & 10464 & 27468 & 0.08 & 0.44 & 0.13 & 1.07 & 1.72 \\
\hline \multirow[t]{2}{*}{ Total } & $2000 / 01$ & 160997 & & & & & 18244 & 62779 & 13824 & 66150 & 0.14 & 1.03 & 0.17 & 2.58 & 3.92 \\
\hline & $2002 / 03$ & 175985 & & & & & 16184 & 75513 & 20542 & 63747 & 0.12 & 1.23 & 0.26 & 2.49 & 4.10 \\
\hline
\end{tabular}

IM: Immature males, MM: Mature male, IF: Immature female, MF: Mature female

TABLE 8. Seasonal prey consumption and feeding impact on the krill resource of Antarctic minke whales in Areas IV and V (Murase et al., MS 2006).

\begin{tabular}{lcccccc}
\hline & & \multicolumn{2}{c}{ Abundance Prey consumption } & & \multicolumn{2}{c}{ Krill biomass } \\
\cline { 7 - 8 } \cline { 6 - 7 } Area & Year & (inds.) & (million $\mathrm{t})$ & & (million t) & (\% of whale's feeding) \\
\hline IV & $1999 / 00$ & 44931 & 0.9 & & 34.2 & 2.7 \\
& $2001 / 02$ & 48280 & 1.1 & & 34.1 & 3.2 \\
V & $2000 / 01$ & 160997 & 3.9 & & 20.7 & 18.9 \\
& $2002 / 03$ & 175985 & 4.1 & & 22.6 & 18.2 \\
\hline
\end{tabular}

increases close to the continental shelf break and further off the shelf (Thomas and Green, 1988). Regional differences of the prey species of the minke whales might reflect changes in the distribution of these prey species in the research area. Direct comparison between stomach contents and prey availability in small areas is necessary for future research.

\section{The diurnal feeding rhythm}

Our results suggested that Antarctic minke whales have a diurnal feeding rhythm, with a primary peak early in the morning. This coincided with results of previous reports (Ohsumi, 1979; Bushuev, 1986). Other studies on common minke whales (B. acutrostrata) in the Northern Hemisphere have shown a tendency for a diurnal feeding activity (Haug et al., 1997; Lindstrøm et al., 1998). In the eastern North Atlantic and western North Pacific, they might not feed at night (Folkow and Blix, 1993; Haug et al., 1997; Tamura, MS 1998). The diurnal pattern seems to be similar to that found in North Atlantic fin whales (Vikingsson 1997). Our result indicates that Antarctic minke whales ceased to feed at earlier time in the day due to the satisfaction with feeding. The maximum amounts of prey found in the stomachs indicate that daily energyrequirement can be met with a single stomach fill. For fin whale off Iceland, Vikingsson (1997) estimated that the mean passage time from the forestomach to fundus was 3-6 h, and that from the forestomach to the anus around 15-18 h. Our result support his estimation.

JARPA has not conducted research activity at night. Whether or not the minke whales feed on prey at night needs to be confirmed using methodology such as the depth data logger system in future.

\section{Daily prey consumption of Antarctic minke whales}

Previous estimates of daily prey consumption rates using respiratory allometry of male and female Antarctic minke whales during the austral summer were 6.7 and $6.2 \%$ of body weight, respectively (Armstrong and Siegfried, 1991). These may be overestimates because those values would require a maximum of two feeding 
times per day for daily energy requirement. However the results of this study indicated a range of maximum weight of stomach contents from 3.1 to $4.2 \%$ of their body weight. Furthermore our study detected only one peak of the diurnal feeding rhythm.

In this study estimates of the daily prey consumption rate ( $\%$ of body weight) ranged from 2.7 to $4.0 \%$ of their body weight (Table 7). These values were similar to the estimates by Lockyer (1981b), Bushuev (1986) and Mori and Butterworth (2004). Using modeling approach, Mori and Butterworth (2004) indicated that the daily prey consumption rate of Antarctic minke whale ranged from 3.0 to $5.0 \%$ of body weight. The estimates from our energy requirements calculations almost corresponded with the results of maximum weight of stomach content in the field data. Therefore these results can be used with confidence as the estimation of daily prey consumption by Antarctic minke whales.

The issue of seasonal energy deposition and body condition of North Atlantic fin and sei whales were discussed by Vikingsson (1995) and Lockyer (1987). As next step the assessment of geographical, monthly and yearly change in the energy requirements of Antarctic minke whales should be investigated. The output from these analyses will be important for the development of ecosystem models.

\section{Some uncertainties in the prey consumption esti- mates}

The important parameters used for estimating prey consumption in this study are the energy contents of prey, muscle and blubber. However, in this study these values were calculated on the basis of very few samples. To account for differences within the season a large number of samples should be examined in the future.

Regarding residence time of Antarctic minke whale in the feeding ground in this study we assumed a period of 120 days for mature females. Baleen whales are generally known to migrate between feeding grounds in high latitudinal waters in summer and the breeding grounds in low latitudinal waters in winter. The ratio of high to low feeding seasons and the proportion of the energy intake per year during the high feeding season are assumed without actual data. This could bring some uncertainty to the estimations. It might be possible in the near future to provide information on residence time using satellite tagging.

There are several models available to estimate whale consumption (see review by Leaper and Lavigne, 2007). Future analyses should evaluate the extent of change in prey consumption estimate derived from using different models.

\section{Prey consumption as an input parameter for ecosys- tem modeling}

In the Southern Ocean, large baleen whale species were depleted drastically in the $20^{\text {th }}$ century. Laws (1977) suggested that before the 1970s, blue (B. musculus) and humpback (Megaptera novaeangliae) whales were the most harvested and were reduced to about 3 and $5 \%$ of their initial biomasses, respectively. Fin (B. physalus) was reduced to about $20 \%$ of their initial biomasses. This rapid decreasing of large baleen whale species provided the annual surplus of krill as much as 150 million $t$ (Laws, 1977). This surplus became available for other krill predators, such as Antarctic minke whale, crabeater seal (Lobodon carcinophagus), Antarctic fur seal (A. gazella), some penguins and sea birds. This phenomenon is called "krill surplus from the depletion of baleen whales".

In the South Atlantic sector of the Southern Ocean, Reilly et al. (2004) estimated the total prey consumption by baleen whales and the feeding impact on krill resources in 2000 . The total prey consumption was estimated between 1.6 and 2.7 million $\mathrm{t}$. This range is approximately $4-6 \%$ of the krill resources. The total prey consumption by other krill predators such as seabirds and pinnipeds was estimated 16 million $t$ in this region (Croxall et al., 1985). This consumption was ten times greater than that estimates by baleen whales.

In our study region, the total prey consumption by baleen whales was estimated between 0.9 and 4.1 million $\mathrm{t}$. This range is approximately $2.7-18.9 \%$ of the krill resources. At present there is little information about the consumption of other krill predators such as seabirds and pinnipeds in our study region for comparison with our results.

Mori and Butterworth (2004) indicated that trend of abundance of Antarctic minke whale had declined after the 1980s using multispecies interaction model including Antarctic minke whale, blue whale and krill in the Southern Oceans. The causes of the decrease in abundance of Antarctic minke whale seem to be abundance over carrying capacity of Antarctic minke whales, competition among Antarctic minke whales, some baleen whales such as blue, fin and humpback whales and some predators such as seals and sea birds, or decreasing of krill biomass due to environment changes.

In a recent study, regression analyses clearly showed that blubber thickness, girth and fat weight have been de- 
creasing for nearly two decades using catch data from all 18 survey years in the JARPA (Konishi et al., 2008). This phenomenon shows that an increase in the abundance of other krill feeders than minke whales and a resulting decrease in the krill population must be considered as a likely explanation.

In the future it is important to investigate the trend of population dynamics among krill and krill predators such as baleen whales, seals and sea birds in the Southern Ocean for management of Antarctic ecosystem. For consideration of ecosystem interaction, many data sets such as natural mortality, birth rate, abundance, per capita of consumption, prey biomass are required.

Therefore, estimates of many parameters for applying in the multi-species ecosystem modeling should be improved in the future. To improve estimates of the daily and seasonal consumption by the minke whales is also important one. Our results are useful to apply as the input data of daily consumption by the minke whales in the entire Southern Ocean for ecosystem-based management. However, our estimates do not account for geographical, monthly and yearly change of their energy requirements.

As next step, the assessment of geographical, monthly and yearly change of their energy requirements by the minke whales is needed. Furthermore, the present results should be compared with information on krill resources and other krill predator's distribution and consumption.

\section{Acknowledgements}

We thank cruise leaders, researchers and crew members of the JARPA surveys conducted between the austral summer seasons of 1989/1990-2004/2005 for collecting data used in the present study. The stomach contents examined in this study were collected by many researchers and crews. Our sincere thank to H. Hatanaka, L.A. Pastene of the Institute of Cetacean Research (ICR) and T. Ichii of the National Research Institute of Far Seas Fisheries for their valuable suggestions and useful comments on this paper.

\section{References}

ARMSTRONG, A. J., and W. R. SIEGFRIED. 1991. Consumption of Antarctic krill by minke whales. Antarct. Sci., 3: 13-18. doi:10.1017/S0954102091000044

BAKER, A., DE C., B. P. BODEN, and E. BRINTON. 1990. A practical guide to the euphausiids of the world. Natural History Museum Publications, London, 96 p.

BARNARD, K. H. 1932. Amphipoda. Discovery Rep., 5:
$1-326$.

BEST, P. B. 1982. Seasonal abundance, feeding, reproduction, age and growth in minke whale off Durban (with incidental observations from the Antarctic). Rep. Int. Whal. Comm., 32: 759-786.

BOYD, I. L. 2002. Estimating food consumption of marine predators: Antarctic fur seals and macaroni penguins. J. Appl. Ecol., 39: 103-119. doi:10.1046/j.13652664.2002.00697.x

BUSHUEV, S. G. 1986. Feeding of minke whales, Balaenoptera acutorostrata, in the Antarctic. Rep. Int. Whal. Comm., 36: 241-245.

CROXALL, J. P., P. A. PRINCE, and C. RICKETS. 1985. Relationships between prey life-cycles and the extent, nature and timing of seal and seabird predation in the Scotia Sea. In: Antarctic Nutrient Cycles and Food Webs. W. R. Siegfried, P. R. Condy, and R. M. Laws, (eds.). Springer, Berlin and Heidelberg, p. 516-533.

DOIDGE, D. W., and J. P. CROXALL. 1985. Diet and energy budget of the Antarctic fur seal, Arctocephalus gazelle, at South Georgia. In: Antarctic Nutrient Cycles and Food Webs W. R. Siegfried, P. R. Condy, and R. M. Laws (eds.). Springer-Verlag, Berlin, Heidelberg, p. 543-550.

FISCHER, W., and J. C. HUREAU. (eds.). 1985a. FAO species identification sheets for fishery purposes. Southern Ocean (Fishing areas 48, 58 and 88) (CCAMLA Convention Area). FAO, Rome, Vol. 1, p. 1-232.

1985b. FAO species identification sheets for fishery purposes. Southern Ocean (Fishing areas 48, 58 and 88) (CCAMLA Convention Area). FAO, Rome, Vol. 2, p. 233-470.

FOLKOW, L. P., and A. S. BLIX. 1993. Daily changes in surfacing rates of minke whales (Balaenoptera acutoro strata) in Norwegian waters. Rep. Int. Whal. Comm., 43: 311-314.

HAKAMADA, H., K. MATSUOKA, and S. NISHIWAKI. MS 2006. An update of Antarctic minke whales abundance estimate based on JARPA data. Paper SC/D06/J6 presented to the Intercessional Workshop to Review Data and Results from Special Permit Research on Minke Whales in the Antarctic, Tokyo, December 2006 (unpublished). 34p. http://www.icrwhale.org/eng/SC-D06-J6.pdf

HAUG, T., K. T. NILSSEN, U. LINDSTRØM, and H. J. SKAUG. 1997. On the variation in size and composition of minke whale (Balaenoptera acutorostrata) forestomach contents. J. Northw. Atl. Fish. Sci., 22: 105-114. doi:10.2960/J.v22.a9

HORWOOD, J. 1990. Biology and exploitation of the minke whale. CRC Press, Inc., Boca Ration Florida, 238p.

HOSOKAWA, H., and T. KAMIYA. 1971. Some observations on the cetacean stomachs, with special considerations on the feeding habits of whales. Sci. Rep. Whales Res. Inst., 23: 91-101.

ICHII, T., and H. KATO. 1991. Food and daily food consumption of southern minke whales in the Antarctic. Polar Biol., 11: 479-487. doi:10.1007/BF00233083

KASAMATSU, F., S. NISHIWAKI, and H. ISHIKAWA. 1995. Breeding areas and southbound migrations of southern minke whales Balaenoptera acutorostrata. Mar. Ecol. 
Prog. Ser, 119: 1-10. doi:10.3354/meps119001

KASAMATSU, F., G. G. JOYCE, P. ENSOR, and J. MERMOZ. 1996. Current occurrence of baleen whales in Antarctic waters. Rep. Int. Whal. Comm., 46: 293-304.

KATO, H., H. KISHINO, and Y. FUJISE. 1990. Some analyses on age composition and segregation of southern minke whales using samples obtained from the Japanese feasibility study in 1987/88. Rep. Int. Whal. Commn., 40: 249-256.

KAWAMURA, A. 1980. A review of food of Balaenopterid whales. Sci. Rep. Whales Res. Inst., 32: 155-197.

KLEIBER, M. 1961. The Fire of Life. J. Wiley and Sons Inc., New York and London, $454 \mathrm{p}$.

KONISHI, K., T. TAMURA, R. ZENITANI, T. BANDO, H. KATO, and L. WALLØE. 2008. Decline in energy storage in the Antarctic minke whale (Balaenoptera bonaerensis) in the Southern Ocean. Polar Biol., 31: 1509-1520. doi:10.1007/s00300-008-0491-3

LAWS, R. M. 1977. Seals and whales of the Southern Ocean. Phil. Trans. R. Soc. Lond. B., 279: 81-96.

LEAPER, R., and D. LAVIGNE. 2007. How much do large whale eat? J. Cetacean Res. Manage., 9: 179-188.

LINDSTRØM U, T. FUJISE, T. HAUG, and T. TAMURA. 1998. Feeding habits of western North Pacific minke whales, Balaenoptera acutorostrata, as observed in JulySeptember 1996. Rep. Int. Whal. Comm., 48: 463-469.

LOCKYER, C. 1981a. Estimation of the energy costs of growth, maintenance and reproduction in the female minke whale, (Balaenoptera acutorostrata), from the southern hemisphere. Rep. Int. Whal. Comm., 31: 337-343.

$1981 b$. Growth and energy budgets of large baleen whales from the Southern Hemisphere. In: Mammals in the Seas, vol. 3. FAO Fisheries Series., 5: 379-487.

1987. Evaluation of the role of fat reserves in relation to the ecology of North Atlantic fin and sea whales. In: Approaches to marine Mammal Energetic. Huntley, A. C., Costa, D. P., Worthy, G. A. J., and M. A. Castellany (eds.). Lawrence: Society for Marine Mammalogy, Special Publication No. 1, 183-203.

MARKUSSEN, N. H., M. RYG, and C. LYDERSEN. 1992. Food consumption of the NE Atlantic minke whale (Balaenoptera acutorostrata) population estimated with a simulation model. ICES J. Mar. Sci., 49: 317-323. doi:10.1093/icesjms/49.3.317

MILLER, D. G. M., and I. HAMPTON. 1989. Biology and ecology of the Antarctic krill (Euphausia superba Dana): a review. BIOMASS Scientific Series., 9: 1-166.

MORI, M., and D. S. BUTTERWORTH. 2004. Consideration of multispecies interactions in the Antarctic: A prelimi- nary model of the minke whale-Blue whale- Krill interaction. Afr. J Mar. Sci., 26: 245-259.

MURASE, H., H. KIWADA, K. MATSUOKA, and S. NISHIWAKI. MS 2006. Results of the cetacean prey survey using a quantitative echo sounder in JARPA from 1998/99 to 2004/2005. Paper SC/D06/J21 presented to the Intersessional Workshop to Review Data and Results from Special Permit Research on Minke Whales in the Antarctic, Tokyo, December 2006 (unpublished), 15 p. http:/www. icrwhale.org/eng/SC-D06-J21.pdf

NISHIWAKI, S., H. ISHIKAWA, and Y. FUJISE. MS 2006. Review of general methodology and survey procedure under the JARPA. Paper SC/D06/J2 presented to the Intercessional Workshop to Review Data and Results from Special Permit Research on Minke Whales in the Antarctic, Tokyo, December 2006 (unpublished), 47 p. http:// www.icrwhale.org/eng/SC-D06-J2.pdf

NORDØY, E. S., L. P. FOLKOW, P. E. MÅRTENSSON, and A. S. BLIX. 1995. Food requirements of Northeast Atlantic minke whales. In: Whales, Seals, Fish and Man. A. S. Blix, L. Walløe, and Ø. Ulltang (eds.). Dev. Mar. Bio., 4: 307-317.

OHSUMI, S. 1979. Feeding habits of the minke whale in the Antarctic. Rep. Int. Whal. Comm., 29: 473-476.

OLSEN, M. A., E. S. NORDØY, A. S. BLIX, and S. D. MATHIESEN. 1994. Functional anatomy of the gastrointestinal system of Northeastern Atlantic minke whales (Balaenoptera acutorostrata). J. Zool., 234: 55-74. doi:10.1111/j.1469-7998.1994.tb06056.x

REILlY, S., S. HEDLEY, J. BORBERG, R. HEWITT, D. THIELE, J. WATKINS, and M. NAGANOBU. 2004. Biomass and energy transfer to baleen whales in the South Atlantic sector of the Southern Ocean. Deep-Sea Res. Pt. II., 51A: 1397-1409.

TAMURA, T. MS 1998. The study of feeding ecology of minke whales in the Northwest Pacific and the Antarctic. PhD thesis, Hokkaido University, Hakodate (in Japanese).

THOMAS, P. G., and K. GREEN. 1988. Distribution of Euphausia crystallorophias within Prydz Bay and its importance to the inshore marine ecosystem. Polar Biol., 8: 27-331. doi:10.1007/BF00442023

VIKINGSSON, G. A. 1997. Body condition of fin whales during summer off Iceland. In: Whales, seals, fish and man. A. S. Blix, L. Walløe, and Ø. Ulltang (eds.). Dev. Mar. Biol., 4: 361-369.

1997. Feeding of fin whales (Balaenoptera physalus) off Iceland - Diurnal and seasonal variation and possible rates. J. Northw. Atl. Fish. Sci., 22: 77-89. doi:10.2960/J. v22.a7 